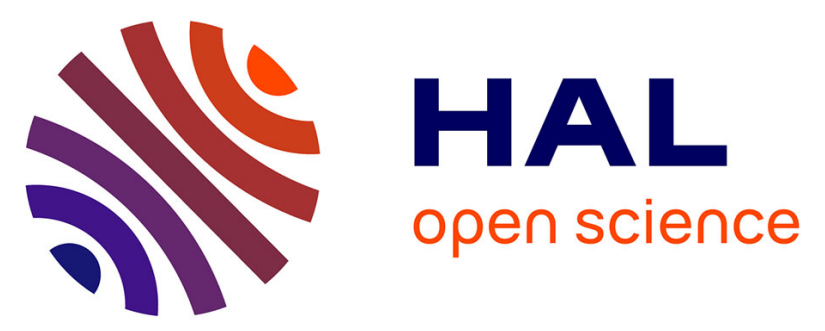

\title{
Chronic exposure to soil salinity in terrestrial species: Does plasticity and underlying physiology differ among specialized ground-dwelling spiders?
}

David Renault, Charlène Puzin, Natacha Foucreau, Alain Bouchereau, Julien Pétillon

\section{To cite this version:}

David Renault, Charlène Puzin, Natacha Foucreau, Alain Bouchereau, Julien Pétillon. Chronic exposure to soil salinity in terrestrial species: Does plasticity and underlying physiology differ among specialized ground-dwelling spiders?. Journal of Insect Physiology, 2016, 90, pp.49-58. 10.1016/j.jinsphys.2016.05.005 . hal-01371663

HAL Id: hal-01371663

https://hal-univ-rennes1.archives-ouvertes.fr/hal-01371663

Submitted on 13 Oct 2016

HAL is a multi-disciplinary open access archive for the deposit and dissemination of scientific research documents, whether they are published or not. The documents may come from teaching and research institutions in France or abroad, or from public or private research centers.
L'archive ouverte pluridisciplinaire HAL, est destinée au dépôt et à la diffusion de documents scientifiques de niveau recherche, publiés ou non, émanant des établissements d'enseignement et de recherche français ou étrangers, des laboratoires publics ou privés. 
Chronic exposure to soil salinity in terrestrial species: does plasticity and underlying physiology differ among specialized ground-dwelling spiders?

Renault D. ${ }^{1}$, Puzin C. ${ }^{2,3}$, Foucreau N. ${ }^{4}$, Bouchereau A. ${ }^{5}$, Pétillon J. ${ }^{2,6}$

${ }^{1}$ Université de Rennes 1, UMR CNRS 6553, 263 Avenue du Gal Leclerc, CS 74205, 35042

Rennes Cedex, France

${ }^{2}$ Université de Rennes 1, EA 7316, 263 Avenue du Général Leclerc, CS 74205, 35042 Rennes Cedex, France

${ }^{3}$ Terrestrial Ecology Unit, Ghent University, K. L. Ledeganckstraat 35, 9000 Ghent, Belgium

${ }^{4}$ Université de Lyon, UMR CNRS 5023 LEHNA, 6 rue Raphaël Dubois, 69622 Villeurbanne Cedex, France

${ }^{5}$ Université de Rennes 1, UMR INRA IGEPP, Campus de Beaulieu, 263 Avenue du Gal Leclerc, CS 74205, 25042 Rennes Cedex, France

${ }^{6}$ Current address: Tropical Conservation Biology and Environmental Science, University of Hawai'i, Hilo, HI 96720, USA

Corresponding author; E-mail: david.renault@univ-rennes1.fr

Tel: +33223236 627; fax: +33223235026 


\section{Abstract}

In salt marshes, the alternation of low and high tides entails rapid shifts of submersion and aerial exposure for terrestrial communities. In these intertidal environments, terrestrial species have to deal with an osmotic loss in body water content and an increase in sodium chloride concentration when salt load increases. In salt marshes, spiders represent an abundant arthropod group, whose physiological ecology in response to variations of soil salinity must be further investigated. In this study, we compared the effect of salinity on the survival and physiology of three species of Lycosidae; two salt marsh species (Árctosa fulvolineata and Pardosa purbeckensis) and one forest species (P. saltans). Spiders were individually exposed at three salinity conditions ( $0 \%, 35 \%$ and $70 \%$ ) and survival, changes in body water content, hemolymph ions $\left(\mathrm{Na}^{+}, \mathrm{Ca}^{2+}, \mathrm{Mg}^{2+}, \mathrm{K}^{+}\right.$; ICP-MS technique) and metabolites (mainly amino acids, polyols, sugars; LC and GC techniques) were assessed. The survival of the forest species $P$. saltans was very quickly hampered at moderate and high salinities. In this spider, variations of hemolymph ions and metabolites revealed a quick loss of physiological homeostasis and a rapid salt-induced dehydration of the specimens. Conversely, high survival durations were measured in the two salt-marsh spiders, and more particularly in A. fulvolineata. In both $P$. purbeckensis and A. fulvolineata, the proportion of $\mathrm{Na}^{+}, \mathrm{Ca}^{2+}, \mathrm{Mg}^{2+}, \mathrm{K}^{+}$remained constant at the three experimental conditions. Accumulation of hemolymph $\mathrm{Na}^{+}$and amino acids (mainly glutamine and proline) demonstrated stronger osmoregulatory capacities in these salt-marsh resident spiders. To conclude, even if phylogenetically close (belonging to the same, monophyletic, family), we found different physiological capacities to cope with salt load among the three tested spider species. Nevertheless, physiological responses to salinity were highly consistent with the realised ecological niches of the spiders.

Key-words: Araneae, ions, amino-acids, sugars, polyols, ICP-MS, UPLC, GC-FID 


\section{Introduction}

Geographical distribution of species correlates with their ecological needs. In this context, physiological plasticity is an important prerequisite for species experiencing varying and varied abiotic conditions (changes in of drought/wet, cold/warm seasons, oxygen and biotic conditions, pH fluctuations, etc..., Spencer \& Gaston 1999). Theoretically, high flexibility should allow thriving in a wider range of habitats. This level of physiological tolerance to abiotic variations is mainly modulated by the ability of organisms to adjust their behaviour, physiology and biochemistry.

In temporary flooded habitats such as salt-marsh, hydrological characteristics (duration, intensity, frequency of drought events) and productivity (nutrient availability) impose physiological constraints to organisms that in turn rule population and species distribution. The alternation of low and high tides entails rapid shifts of submersion and aerial exposure for terrestrial communities. Salt marshes are located between land and marine systems, and their habitats are subjected to regular tides (leading to submergence approximately once per month), which, through their duration, frequency and seasonality, produce variations in soil salinity. In these intertidal environments, species adapted to seawater have to counteract problems of ionic regulation if salt load declines, whereas terrestrial species have to deal with an osmotic loss in body water content and an increase in sodium chloride concentration when salt load increases (Witteveen et al. 1987). Together with the duration of the submersion, all of these parameters drive community structure and diversity (Döbel et al. 1990) as they impact on many physiological functions of salt-marsh fauna (e.g. Levin \& Talley 2000).

The way arthropods cope with salinity (both hypo and hyperosmotic stress) include behavioural (Pétillon et al. 2009, Fanini et al. 2012), morphological (tegument waterproofing: Beament 1961) and physiological (isoconformers: Amphipods; Calosi et al. 2005) responses. Two main strategies can be defined to explain the occurrence of terrestrial species within salt marshes: migrate or survive under water (see Tufova \& Tuf 2005 for a study on the survival underwater of millipedes, centipedes and isopods). A spatial escape of the environmental stress can be observed, and this strategy is often used for short periods of flooding at high tide (Foster \& Treherne 1975, Wyatt 1986, Hadley 1994, Pétillon et al. 2010a). The non-escaping species that stay underwater have evolved adaptations enabling organisms to maintain activity (either metabolic, reproductive and for insects, locomotion) 
during the unfavourable period (Foster 2000), i.e. elevation of soil salinity after flooding events. Indeed, in daily flooded salt marshes, a tidal rhythm of activity is less optimal (Foster 1983, Witteveen \& Joose 1988). The tolerance strategy is often restricted to highly adapted species. The incurred ecological costs associated with tolerance often narrow their distributions to few niches, such as salt marshes (i.e. they should only be found in the habitats exhibiting those specific conditions as a result of the ability of the individual to modify their traits to maximise performance and fitness in this environment). Reduced metabolic rate, structure of the epicuticle (responsible of hygrophobic properties) and elevation of hemolymph osmolality are elements of the arsenal strategies employed by arthropods to combat osmotic stress.

Some studies on Annelids, Crustaceans and Bivalves demonstrated that variations in salinity modify body water content, ionic and osmotic regulation (Moore \& Francis 1985, Sowers et al., 2006). Synthesis of compatible solutes is frequently observed in species exposed to environmental constraints, including osmotic stress. Salinity causes changes in polyols (especially glycerol, sorbitol, myo-inositol), sugars (trehalose) and some amino acids (as proline or alanine) (Edwards 1982, Misra \& Gupta 2005).

In the available literature, the ways terrestrial arthropods, and among them spiders, a dominant group of predators in intertidal habitats (e.g. Pétillon et al. 2005), cope with soil salinity are poorly documented (Foster \& Treherne 1976, Foster 2000; but see Heydemann 1970 for Pardosa purbeckensis; Bethge 1973 for Erigone longipalpis and Foucreau et al. 2012 for Arctosa fulvolineata). In the present work, we compared the effect of soil salinity among three ground-dwelling spider species (Lycosidae), of which two are qualified as salt-marsh "resident" species, Arctosa fulvolineata and Pardosa purbeckensis, whereas the third one, $P$. saltans, is a forest species (and likely not adapted to salinity exposures). Because the realised niche of these species should be correlated with their ecophysiological capabilities (e.g. for ground-dwelling spiders: DeVito et al. 2004, Frick et al. 2007), we first hypothesised survival patterns depending on soil salinity (here, $0 \%, 35 \%$ and $70 \%$ ) to differ among these three species; increasing and decreasing survivals along increasing salinities should be observed for salt-marsh and forest species, respectively. We assumed that body water loss would follow survival patterns. Lastly, we expected synthesis of inorganic and organic osmocompatible solutes to increase with salinity and duration of experiment, but to remain qualitatively similar among species as the three species we studied are phylogenetically 
close (belonging to the same, monophyletic, family: Murphy et al. 2006). This last hypothesis was tested in an exploratory way by measuring changes in ions (by ICP-MS), amino-acid, sugar and polyol levels (by GC-FID) over time and along increasing soil salinities.

\section{Material and Methods}

\subsection{Collection sites}

Experiments were carried out from April to June 2008 using hand-collected spiders: adult females of Pardosa saltans were collected under dead wood and from the litter of a deciduous forest (Paimpont, France, 48 $8^{\circ} 1^{\prime} 0 \mathrm{~N}, 2^{\circ} 10^{\prime} 600$ ); adult females of Pardosa purbeckensis and Arctosa fulvolineata (Araneae: Lycosidae) were sampled in an intertidal salt marsh (Le Vivier sur Mer, Mont St Michel Bay, France, $48^{\circ} 40^{\prime} \mathrm{N}, 1^{\circ} 40^{\prime} \mathrm{O}$ ). After collection, spiders were kept for one day under controlled conditions at constant $20 \pm 1{ }^{\circ} \mathrm{C}$ before being used for experiments. Only females were used in the present study; they exhibit higher survival durations to saline conditions over males (DeVito \& Formanowicz 2003, Pétillon et al. 2011), likely because of their higher energetic reserves (Moya-Laraño et al. 2008).

\subsection{Experimental design}

\subsubsection{Salinity conditions}

Female spiders were individually placed into hermetic plastic boxes $(6 \mathrm{~cm}$ diameter, $7 \mathrm{~cm}$ depth, $125 \mathrm{~mL}$ ), half filled with sand. Three distinct experimental conditions were performed: (i) null salinity (sand and mineral water considered as being non-salted, $0 \%$ salt), medium salinity (sand $\left[\mathrm{ca} .33 \mathrm{~cm}^{3}\right.$ ] and mineral water-35\%o salt [added until saturation of sand]), and high salinity (sand [ca. $33 \mathrm{~cm}^{3}$ ] and mineral water-70\% salt [added until saturation of sand]). The hypersaline condition corresponds to the highest soil salinity the spiders can endure in the monthly-flooded portions of the salt marsh (Pétillon et al. 2010b). Commercial marine salt 'Sel de Guérande' was used for setting the desired salinity. For each species, spiders were individually held into plastic boxes at the three saline conditions (L/D: 16/8, temperature: $20 \pm 1{ }^{\circ} \mathrm{C}$, Relative humidity (RH): $\left.78 \pm 5 \%\right)$. Spiders were food deprived during the whole experiment to standardize the trophic status of the specimens. Soil salinity and hygrometry were monitored with a W.E.T. sensor $(5 \mathrm{~cm}$ depth; specific sand soil calibration) connected to a moisture meter HH2 (both by Delta-T Devices Ltd., Cambridge, 
UK). These parameters did not vary significantly over time till the end of the experiment (see data from Pétillon et al. 2011).

\subsubsection{Survival experiments and body water content}

Salinity tolerance of $A$. fulvolineata, $P$. saltans and $P$. purbeckensis was assessed the three saline conditions $(0,35$ or $70 \%$ ). Survival of spiders was monitored every day until the death of all spiders ( $N=15$ females / species / experimental condition). When assessing the survivorship, females that were not reactive to mechanical stimulation with paintbrush were considered as dead. Mortality was further confirmed by transferring immobile spiders to control conditions (null salinity and access to trophic resources); spiders were reassessed for survival $24 \mathrm{~h}$ later.

In a second experiment, changes in body water content was monitored in the three spider species exposed at the three saline conditions for 0,3 and 7 days ( $P$. saltans) or for 0 , 7 and 14 days (A. fulvolineata and P. purbeckensis). Survival data were considered for the selection of these durations of exposure (maximum mortality was about $30 \%$ for these durations, except for $P$. saltans kept at $70 \%$ for 7 days whose mortality reached $40-50 \%$ ). For each experimental condition, water mass (mg) was measured on 15 spiders immediately after collection (fresh mass; Sartorius A200S, $d=0.1 \mathrm{mg}$ ). Then, females were plunged into liquid nitrogen before being freeze-dried and rapidly reweighed before being stored at - 20 ${ }^{\circ} \mathrm{C}$. Water mass was calculated from these data. Samples exposed for 7 ( $P$. saltans) or 14 ( $P$. purbeckensis and A. fulvolineata) days were further used for metabolic profiling.

\subsubsection{Ion concentration}

Samples of hemolymph were collected from alive spiders maintained at 0,35 or $70 \%$ o salinities for 0 and 7 days (Pardosa saltans) or for 0 and 14 days (A. fulvolineata and $P$. purbeckensis). Four legs of each spider were cut off, and they were immediately placed into $0.2 \mathrm{~mL}$ PCR tubes and centrifuged at $1000 \mathrm{~g}$ for 30 seconds. One biological replicate consisted of the hemolymph gathered from 10 individuals $(\mathrm{N}=2$ biological replicate per experimental condition). The total hemolymph volume of each biological replicate was measured with a calibrated microcapillary tube, and samples were vacuum-dried (Speedvac ${ }^{\mathrm{TM}}$ ) to obtain their dry masses. A $200 \mu \mathrm{L}$ volume of nitric acid was added to each biological replicate, followed by an adding of two droplets of hydrogen peroxide (destruction 
of organic matter and stabilisation of samples for subsequent measurements). This solution was then diluted in $10 \mathrm{~mL}$ of ultrapure water containing $10 \mathrm{ppb}$ of indium (internal standard). Concentrations of four metal ions, $\mathrm{Na}^{+}, \mathrm{K}^{+}, \mathrm{Mg}^{2+}$ and $\mathrm{Ca}^{2+}$ were determined by ICPMS (Agilent Technologies HP4500), with normal plasma conditions, as described in Gaillou et al. (2008). Quantitative analyses were performed using a conventional external calibration procedure (Bouhnik-Le Coz et al. 2001). Calibration curves were calculated from intensity ratios of the internal standard and the analysed elements.

\subsection{Metabolic profiles}

\subsubsection{Sample preparation}

For each experimental condition, five replicates, each consisting of three randomly collected female spiders, were prepared. The samples were resuspended in $1000 \mu \mathrm{L}$ of a methanol: chloroform (2:1, v:v) solution and homogenised with two tungsten beads $(\varnothing: 3 \mathrm{~mm})$ for 2 min at $30 \mathrm{~Hz}$ (Retsch ${ }^{\mathrm{TM}}$ MM301 Retsch GbmH, Haan, Germany). Then, $666 \mu \mathrm{L}$ of ultrapure water was added, and the samples were vortexed, and centrifuged at $4000 \mathrm{~g}$ for $10 \mathrm{~min}$ at 4 ${ }^{\circ} \mathrm{C}$. One aliquot $(700 \mu \mathrm{L})$ of the upper phase was transferred to clean microtubes and vacuum-dried (Speed Vac Concentrator, MiVac, Genevac Ltd., Ipswich, England). Finally, 500 $\mu \mathrm{L}$ of ultrapure water was added to each sample and they were stored to $-80{ }^{\circ} \mathrm{C}$ until analyses.

\subsubsection{Amino acid analysis}

Amino acid analysis was adapted from Renault et al. (2010). Briefly, aliquots (10 $\mu \mathrm{L})$ of the crude aqueous extract were used for amino acids' derivatisation according to the AccQ $\bullet T a g$ Ultra Derivatisation Kit protocol (Waters Corporation, Milford, MA). Amino acids were analysed using an Acquity UPLC ${ }^{\circledR 53}$ system (Waters Corporation, Milford, MA) by injecting $1 \mu \mathrm{L}$ of the derivatisation mix onto an Acquity UPLC ${ }^{\circledR 534} \mathrm{BEH}$ C18 $1.7 \mu \mathrm{m} 2.1 \times 100 \mathrm{~mm}$ column heated at $55{ }^{\circ} \mathrm{C}$. External standards were run and used for the drawing of calibration curves allowing the quantification of metabolites from the samples.

\subsubsection{Sugar and organic acid analysis}

Sugars and organic acids were quantified with the method described by Hidalgo et al. (2013). Briefly, a Trace GC Ultra chromatograph with flame ionization as the detector (GC-FID, Thermo Fischer Scientific Inc., Waltham, MA, USA) was used. The injector temperature was 
held at $260^{\circ} \mathrm{C}$. The oven temperature ranged from 70 to $147^{\circ} \mathrm{C}$ at $9{ }^{\circ} \mathrm{C} \min { }^{-1}$, from 147 to $158{ }^{\circ} \mathrm{C}$ at $0.5^{\circ} \mathrm{C} \min ^{-1} 1$, from 158 to $300^{\circ} \mathrm{C}$ at $5.0^{\circ} \mathrm{C}$ min 1 , and remained for 3 min at $300{ }^{\circ} \mathrm{C}$. A $30 \mathrm{~m}$ fused silica column (DB-5, $30 \mathrm{~m} \times 0.32 \mathrm{~mm} \times 0.25 \mu \mathrm{m}$, 5\%-Phenyl-methylpolysiloxane, 95\% dimethylpolysiloxane) was used, with helium as the carrier gas at a rate of $1 \mathrm{~mL} \cdot \mathrm{min}^{-1}$. For each sample, $100 \mu \mathrm{L}$ of the crude aqueous extract was vacuum-dried, and dry residues were redissolved in $50 \mu \mathrm{L}$ of methoxyamine hydrochloride solution in pyridine $(20 \mathrm{mg} / \mathrm{mL})$. Samples were agitated for $90 \mathrm{~min}$ at $30{ }^{\circ} \mathrm{C}, \quad 50 \mu \mathrm{L}$ of $\mathrm{N}$-methyl- $\mathrm{N}$ (trimethylsilyl)trifluoroacetamide (MSTFA; Sigma) were added, and derivatisation was conducted at $37{ }^{\circ} \mathrm{C}$ for 30 min under agitation. One microliter of each sample was then injected to the gas chromatograph. Chromatograms were deconvoluted using ChemStation v2.0.7, and metabolite levels were quantified using arabinose as internal standard and by comparison with individual external standards.

\subsection{Statistical analysis}

All data are given as means \pm SE. Prior to analysis, normality and homogeneity of variances were checked.

Time-mortality regression equations and hours to $L t_{50}$ along with both 95 and $99 \%$ confidence limits were calculated by probit analysis (Minitab Statistical Software Release 13, Minitab Inc, State College, PA). Confidence limits were used to compare spider survival among experimental conditions: lethal times were significantly different $(P<0.05)$ when the fiducial limits of the two values did not overlap.

The effect of salinity on body water content (ratio [fresh mass - dry mass] / dry mass) over the course of the experiment was investigated with two ways ANOVA, with duration of exposure and salinity treatment as the independent variables, and water content as the dependent variable. $P$ values were adjusted for multiple comparisons with Bonferroni correction. Concentrations in mineral elements were the mean of two replicate samples. For each species, variations of the proportions of the four ions among the three experimental conditions was assessed with $\chi^{2}$ tests.

Concentrations of all metabolites were log-transformed. Effects of species and saline conditions on the metabolic profiles of female spiders were investigated using Partial-Least Squares Discriminant Analysis (PLS-DA). Multiple correlation coefficient $\left(R^{2}\right)$ and crossvalidated $R^{2}\left(Q^{2}\right)$ were used to confirm the predictive power of the fitted model. The 
statistical significance of the PLS-DA was also assessed with permutation tests (1000 permutations, $P<0.001$ ). Variable Importance in Projection (VIP) scores, which are the weighed sums of squares of the PLS loadings, were obtained from the PLS-DA. Analyses of variance were performed on all the metabolites to search for a significant effect of salinity level on their concentrations. Together with the multivariate analysis, one-way ANOVAs were performed for each detected metabolite, with experimental condition (salinity) as explanatory variables. ANOVAs were followed, when required, by Tukey HSD post-hoc procedures among levels of significant factors. The statistical $P$-values were adjusted using the two-stage Benjamini-Hochberg algorithm to control for false discovery rate $(\alpha=0.05)$. These analyses were conducted using the statistical software of ' $R$ 2.13.0' ( $R$ Development Core 2008) and MetaboAnalyst (Xia et al. 2012).

\section{Results}

\subsection{Survival}

Survival of $P$. saltans was highly reduced with increased salinity levels, with $L_{50}$ decreasing from ca. 40 to 10 to 7 days at 0,35 and $70 \%$ respectively (Fig. 1). The duration of survival of $P$. purbeckensis was the lowest of the three species at $0 \%$ o $(P<0.05)$, but these spiders highly significantly outcompete $P$. saltans for survival capacity at 35 and $70 \%$. Finally, females of $A$. fulvolineata were characterised by the highest duration of survival, whatever the saline condition (Fig. 1).

\subsection{Water content}

Body water content was significantly affected by salinity in the three spider species (Table S1, Figure 2). In both $P$. saltans and P. purbeckensis, water content was the lowest the highest salinity when duration of exposure lasted 7 and 14 days, respectively. Water content was the highest at the null salinity in A. fulvolineata (Table S1, Figure 2).

\section{3 lons}

Initial ion concentration in hemolymph, measured after the females were exposed to control condition $\left(20^{\circ} \mathrm{C}\right.$, null salinity) for one day, is presented in table 1 . Concentration of ions in hemolymph varied with saline exposure over the course of the experiment in the three 
spider species (Fig. 3). Overall, the proportion of the four ions varied according to the saline conditions in $P$. saltans $\left(\chi^{2}=8.5, P=0.20\right)$ whereas it remained equivalent in $P$. purbeckensis $\left(\chi^{2}=92.1, P<0.001\right)$ and $A$. fulvolineata $\left(\chi^{2}=53.5, P<0.001\right)$. Levels of $\mathrm{Na}^{+}$were augmented in the three species at 35 and $70 \%$, as compared with $0 \%$-exposed spiders, with the most striking $\mathrm{Na}^{+}$elevation being recorded in $P$. saltans (4-fold increase of $\mathrm{Na}^{+}$concentration in between 0 and 35\%). In this species, concentrations of the three other ions $\left(\mathrm{Mg}^{2+}, \mathrm{K}^{+}\right.$and $\mathrm{Ca}^{2+}$ ) were also increased when salt concentration rose (Fig. 3); total hemolymph ions highly rose with salinity. For $P$. purbeckensis; total hemolymph ions was similar at 0 and $35 \%$ and slightly (not statistically significant) decreased at 70\%o (Fig. 3). Finally, In A. fulvolineata, both $\mathrm{Ca}^{2+}$ and $\mathrm{Mg}^{2+}$ had nonsignificant elevated concentrations with increasing saline conditions, resulting in total hemolymph ions higher at 35 and $70 \%$.

\subsection{Metabolic profiles}

A set of 34 metabolites was identified in the spiders with our chromatographic procedure, including amino acids, carboxylic acids, cyclitols, polyamines, polyhydroxy acids, polyols and sugars. PLS-DA containing all experimental samples revealed the existence of significant differences among the groups (Permutation tests; $P<0.001,0 / 1000$ ). Thus, in the subsequent analyses, the effect of salinity on metabolite concentration was assessed at the species level.

The PLS-DA depicting the class separation by the 34 discriminant variables in $P$. saltans is presented in figure 4 . In this species, the first (LD1) and second (LD2) Linear Discriminant axes accounted for 47.8 and $10.1 \%$ of the total inertia (the inertia is the total variance of a dataset), respectively. The amounts of 11 metabolites, of which $\alpha$-alanine, myo-inositol, proline, serine, succinic acid and tryptophane can be mentioned, varied with increased salinity level (Fig. 4, Table S2). LD1 separated females maintained at null salinity from females acclimated at 35 and $70 \%$, females from these two latest groups had overlapping metabolic profiles (Fig. 4).

For P. purbeckensis, LD1 and LD2 accounted for 28.7 and $46.5 \%$ of total inertia, respectively (Fig. 5). Two main groups were observed: spiders exposed at $0 \%$ on the one hand, and spiders exposed at 35 and $70 \%$ salinities, whose metabolic profiles overlapped, on the other hand. Increasing concentrations of eight metabolites, including aspartate, 
glutamine, malate and proline, were measured from female $P$. purbeckensis exposed to augmented salinity levels (Fig. 5, Table S2). Conversely, two metabolites were characterised by decreased amounts at higher salinities (lysine and serine).

Variations of the 34 metabolites across the saline conditions are presented in Figure 6 for female Arctosa fulvolineata. The first (LD1) and second (LD2) Linear Discriminant axes accounted for 36.3 and $13.3 \%$ of total inertia, respectively. For this species, the three experimental groups were separated on LD1 according to increasing salinity levels. The VIP scores showed that separation on LD1 was mainly due to increasing levels of 12 metabolites. Eight metabolites, including asparagine, glutamine and proline had augmented amounts with elevated salinity amount rose, whereas four metabolites, including lysine, had decreased amounts (Fig. 6, Table S2).

\section{Discussion}

In the present work, we compared the physiological responses to salinity of three grounddwelling spiders, P. saltans, P. purbeckensis, and A. fulvolineata, thriving in distinct habitats. Even if phylogenetically close, the three tested spider species exhibited different physiological capacities to cope with salt load, and physiological responses to salinity were highly consistent with their realised ecological niches.

Survival

Survival of the forest spider was quickly hampered at medium and high salinities, which is consistent with our previous experiment on other species from the Pardosa genus (Pétillon et al. 2011). Pardosa saltans is mostly restricted to the wet litter layer of deciduous forests (e.g. Hendrickx et al. 2001), where salinity is highly likely low. This finding also suggests that the ability to cope with saline exposure requires the development of specific physiological and metabolic strategies in this species (see Bradley 2008, for a synthesis on the evolution of salinity tolerance in mosquitoes). Consistently, both salt-marsh inhabiting species ( $P$. purbeckensis and $A$. fulvolineata) greatly outcompeted $P$. saltans in terms of salinity tolerance. The highest capability to cope with salinity was measured in $A$. fulvolineata, with half of the individuals being able to survive prolonged exposures (up to 36 days) at salinity levels twice higher than that of the sea. This spider thrives in humid sediments, in the first four centimeters of the ground, where salt likely accumulates and 
necessitates enhanced osmoregulatory capacities. Finally, survival remained higher at $0 \%$ in these two salt-marsh species. This finding delineates the physiological costs required for combatting salt load and underscores that salt is not a prerequisite for the survival of $A$. fulvolineata and $P$. purbeckensis. Thus, biotic interactions, rather than salinity, likely represent an important driver of the distribution of terrestrial spiders in saline habitats (Carbonell et al. 2012).

\section{Water and ion contents}

Arthropods facing hypertonic environments are usually prone to dehydration. The decreased body water content of the two ground-dwelling spiders (Pardosa sp.) with increasing salinity is congruent with this assumption. Interestingly, the highest amount of body water lost was measured in the resident salt-marsh spider $P$. purbeckensis exposed at $70 \%$. Moloney \& Nicolson (1984) showed that loss of water the middle shore living spider Desis formidabilis was higher than that of Amaurobioides africanus, which lives at higher elevations in the shore. We did not report such a difference in the spatial distribution of $A$. fulvolineata and $P$. purbeckensis, and, alternatively differential respiration and excretion losses (Walter et al. 2012) could explain the distinct body water patterns between these two salt-marsh spider pecies.

Inter-specific variations in the amount of body water lost have already been measured in spiders (likely explained by active secretion of epidermal cells: Davies \& Edney 1952). In spiders, water may be mainly lost from hemolymph (which represents almost $32 \%$ of female fresh mass in lycosid species: Carrel 1990). This assumption is congruent with the conclusions drawn from other taxa like amphipods (Moore \& Francis 1985) and isopods (Holdrich \& Mayes 1976).

Differences in the ionic composition of hemolymph was observed among the three spider species. Such qualitative and quantitative differences are consistent with the primary literature, with ionic composition varying according to the feeding preferences of the specimens (Djamgoz 1987, Zeiske 1992). Body water content and, depending on spider species and experimental saline conditions, concentration of metal ions $\left(\mathrm{Ca}^{2+}, \mathrm{K}^{+}, \mathrm{Mg}^{2+}, \mathrm{Na}^{+}\right)$ were differentially altered among species. High variations of ion levels were observed in $P$. saltans, with maximum ionic concentrations recorded in specimens exposed at $35 \%$. Together with the survival results, this pattern strongly suggests a dysregulation of ion 
regulation (Yancey 2005), as soon as this species is subjected to elevated salt load. In turn, this results in a quick loss of physiological homeostasis and a progressive salt-induced dehydration of $P$. saltans females, which may have provoked DNA breaks, protein denaturation, and uncontrolled molecular interactions (Benoit et al. 2009, Gusev et al. 2010). The increased $\left[K^{+}\right]$with salinity in $P$. saltans also supports this assumption, as augmentation of $\left[\mathrm{K}^{+}\right]$has been correlated to accumulation of injuries, and ultimately mortality, in cold-exposed insects (Koštál et al. 2007). In this work, we gathered evidence of the limited ability of $P$. saltans to cope with salinity, thus partially explaining its distribution restricted to forest habitats.

A different story emerges for the two salt-marsh spiders, whose proportions of the four ions were not altered by salinity treatments. The high survival duration, decreased body water content of $A$. fulvolineata from 0 to $70 \%$ salinities, and concomitant increase in $\left[\mathrm{Na}^{+}\right]$, probably depict osmoregulatory adjustments. Sodium has been reported as one of the most osmotic active constituents in hemolymph of insects (Ramsey 1950, Edney 1977) and spiders (Nentwig 1987, Moloney \& Nicolson 1984) facing saline stress. Tracking variations in osmotic pressure of the environment requires in-time adjustments of osmolarity of the body fluids, a mechanism that is typical from osmoconformer species. Conversely, females of $P$. purbeckensis rather behave as osmoregulators, with global ionic concentrations maintained constant at salinities of 0 and $35 \%$. At the highest salinity, the accumulation of organic solutes may have contributed to augment hemolymph osmolality, thus necessitating a reduction $\left[\mathrm{Na}^{+}\right]$in the supposed osmoregulator P. purbeckensis. Heydemann (1970) previously showed a better regulation of $\mathrm{Na}^{+}$levels in $P$. purbeckensis as compared to the eurytopic $P$. amentata

\section{Metabolites}

The amassing of several metabolites has been assumed to aid species to overcome saline stress (Patrick \& Bradley 2000, Foucreau et al. 2012, Hidalgo et al. 2013). Among the different classes of organic compounds, amino acids are generally efficient contributors for the regulation of cell volume (Yancey 2005). In spiders, adaptations to osmotic stress is achieved through the production of osmo-protectants, or by the selection of preys containing particular amino acids and/or sugars have been reported for spiders (see Heydemann 1970 for Pardosa purbeckensis; Bethge 1973 for Erigone longipalpis). Overall, 
our data are consistent with the literature: accumulation of amino acids, which were generally measured in higher amounts in P. purbeckensis and $A$. fulvolineata as compared to P. saltans, likely played important osmoregulatory role during saline exposure. Specifically, asparagine, aspartic acid, glutamine, proline, and serine were all increased with increasing salinity in the three spider species in this study.

Asparagine and alanine can be synthesised intensively in organisms in response to salt stress (Witteveen et al. 1987). Alanine represents a common feature in several salt-exposed organisms (Patrick \& Bradley 2000; Renault et al. 2014), including spiders (Foucreau et al. 2012). Alanine, only accumulated significantly in $P$. saltans and $P$. purbeckensis, is an important contributor of intracellular osmoregulatory processes (Holmstrup \& Bayley 2013). In this line, the large concentrations of aspartic acid in the two Pardosa spiders exposed to saline conditions should be underscored. Indeed, this accumulation is consistent with the alanine-oriented synthesis in salt-exposed spiders, as a quick additional build-up of alanine can be achieved through intense decarboxylation of aspartic acid (Kasschau et al. 1984). Alternatively, in P. saltans particularly, it cannot be excluded that the increasing amounts of aspartic acid could result from the detrimental effects of $\mathrm{NaCl}$ on enzyme activities, as hypersaline conditions affect the activity aspartate transaminase (Pollard \& Wyn Jones 1979)

Proline is often accumulated at high levels in halophyte plants, bacteria or insects subjected to salt load (Misra \& Gupta 2005). The physicochemical characteristics of this amino acid make it an excellent osmolyte, and it acts as regulator of the osmotic pressure at the cellular level during salt stress (Stewart \& Lee 1974). Interestingly, proline concentrations measured from $P$. purbeckensis exposed at salinities of 35 and $70 \%$ were three times higher than in the two other species. Such an elevation in the concentration of this amino acid highly likely contributed to augmenting hemolymph osmolality, which is consistent with the above-discussed variations of $\left[\mathrm{Na}^{+}\right]$in $P$. purbeckensis.

Amounts of circulating glutamine can be high in non-stressed arthropods (Evans \& Crossley 1974). This metabolite plays a prominent role in the control of cell volume, especially in shrunk cells (Fumarola et al. 2001), and also stimulates fluid secretion (Hazel et al. 2003). The increased amounts of this amino acid suggest its possible osmoregulatory role in the three spider species over the salinity gradient.

Interestingly, sugars varied little in the present work, but we cannot rule out their involvement in coping with saline exposure. Indeed, their energetic importance for fuelling 
the metabolism together with food deprivation imposed to the spiders may have masked their possible role in balancing osmotic stress

\section{Conclusion}

The two salt-marsh species P. purbeckensis and A. fulvolineata exhibited strong abilities to deal with salty environments as compared with the forest species, $P$. saltans. This finding is consistent with the realised ecological niches of these spiders. Also, we demonstrated that both $P$. purbeckensis and $A$. fulvolineata are not strict halophilic spiders. Their salt marsh restricted distribution is permitted by enhanced osmoregulatory capacities, either by osmoregulation ( $P$. purbeckensis) or osmoconformation (A. fulvolineata). Meanwhile, these spiders were also characterised by strong abilities to live in unsalted situations. It should be evaluated in future studies if their adaptations allowing thriving in salt-marsh is associated with poorer competitiveness, explaining their habitat distribution restricted to salt marshes. Finally, the well-being of spiders exposed to saline gradients could be evaluated in future studies. For instance, the variations of HSC7O expression could be monitored, as these proteins have been suggested as a relevant molecular indicator for that purpose in a carabid beetle exposed to saline conditions (Siaussat et al. 2013).

\section{Acknowledgements}

The authors like to thank Stéphane Chantepie, Clément Donnerh, Sonia Dourlot, Véronique Dubois, Floriane Karas, Rémi Leménicier, Boris Leroy and Fabienne Perron for help in collecting the spiders, Martine Bouhnik-Le Coz for handling the samples during ion measurement, and Ellie Armstrong for English editing.

\section{References}

Beament, J.W.L., 1961. The waterproofing mechanism of arthropods: II. The permeability of the cuticle of some aquatic insects. Journal of Experimental Biology, 38, 277-290.

Benoit, J.B., Lopez-Martinez, G., Elnitsky, M.A., Lee, R.E., Denlinger, D.L. 2009. Dehydrationinduced cross tolerance of Belgica antarctica larvae to cold and heat is facilitated by trehalose accumulation. Comparative Biochemistry and Physiology A, 152, 518-523. 
Bethge, W., 1973. Ökologische-physiologische Untersuchungen über die Bindung von Erigone longipalpis (Araneae, Micryphantidae) an das Litoral. FaunistischÖkologischen Mitteilungen, 4, 223-240.

Bouhnik-Le Coz, M., Petitjean, P., Serrat, E., Gruau, G., 2001. Validation d'un protocole permettant le dosage simultané des cations majeurs et traces dans les eaux douces naturelles par ICP-MS. Collection Les Cahiers Techniques de Géosciences Rennes, 1, 1-99.

Bradley T.J. 2008. Saline-water insects: Ecology, physiology and evolution. In Aquatic insects: challenges to populations. Proceedings of the Royal Entomological Society's 24th symposium, Lancaster J. \& Briers R.A. (eds). Cab International, Wallingford, UK, 332p.

Calosi, P., Ugolini, A., Morritt, D., 2005. Physiological responses to hyposmotic stress in the supralittoral amphipod Talitrus saltator (Crustacea: Amphipoda). Comparative Biochemistry and Physiology, Part A: Molecular and Integrative Physiology, 142, 267275.

Carbonell, J.A., Millán, A., Velasco, J., 2012. Concordance between realised and fundamental niches in three Iberian Sigara species (Hemiptera: Corixidae) along a gradient of salinity and anionic composition. Freshwater Biology, 57, 2580-2590.

Carrel, J.E., 1990. Water and hemolymph content in the wolf spider Lycosa ceratiola (Araneae, Lycosidae). Journal of Arachnology, 18, 35-40.

Davies, M.E., Edney, E.B., 1952. The evaporation of water from spiders. Journal of Experimental Biology, 29, 571-582.

DeVito, J., Formanowicz Jr., D.R., 2003. The effects of size, sex, and reproductive condition on thermal and desiccation stress in a riparian spider (Pirata sedentarius, Araneae, Lycosidae). Journal of Arachnology, 31, 278-284.

DeVito, J., Meik, J.M., Gerson, M.M., Formanowicz Jr., D.R., 2004. Physiological tolerances of three sympatric riparian wolf spiders (Araneae: Lycosidae) correspond with microhabitat partitioning. Canadian Journal of Zoology, 82, 1119-1125.

Djamgoz, M.B.A., 1987. Insect muscle: Intracellular ion concentrations and mechanisms of resting potential generation. Journal of Insect Physiology, 33, 287-314.

Döbel, H.G., Denno, R.F., Coddington, J.A. 1990. Spider (Araneae) community structure in an intertidal salt marsh: effects of vegetation structure and tidal flooding. Environmental Entomology, 19, 1356-1370. 
Edney, E.B., 1977, Water balance in land arthropods. Springer Verlag, Berlin.

Edwards, H.A., 1982. Free amino acids as regulators of osmotic pressure in aquatic insect larvae. Journal of Experimental Biology, 101, 153-160.

Evans, P.D., Crossley, A.C., 1974. Free amino acids in the haemoytes and plasma of the larva of Calliphora vicina. Journal of Experimental Biology, 61, 463-472.

Fanini, L.A., Marchetti, G.M., Baczewska, A., Sztybor, K., Scapini, F., 2012. Behavioural adaptations to different salinities in the sandhopper Talitrus saltator: Mediterranean vs Baltic populations. Marine and Freshwater Research, 63, 275-281.

Foster, W.A., 1983. Activity rhythms and the tide in a saltmarsh beetle Dicheirotrichus gustavii. Oecologia, 60, 111-113.

Foster, W.A., 2000. Coping with the tides: adaptations of insects and arachnids from British saltmarshes, in: Sherwood, B.R., Gardiner, B.G., Harris, T. (Eds.), British saltmarshes. Forrest Text, Tresaith, pp. 203-221.

Foster, W.A., Treherne, J.E., 1975. The distribution of an intertidal aphid, Pemphigus trehernei Foster, on marine saltmarshes. Oecologia, 21, 141-155.

Foster, W.A., Treherne, J.E., 1976. Insects of marine saltmarshes: problems and adaptations, in: Cheng, L. (Ed.), Marine insects. North-Holland Company, Amsterdam, pp. 5-42.

Foucreau, N., Renault, D., Lugan, R., Hidalgo, K., Pétillon, J., 2012. Effects of diet and salinity on the survival, egg laying and metabolic fingerprints of the ground-dwelling spider Arctosa fulvolineata (Araneae, Lycosidae). Comparative Biochemistry and Physiology Part A: Molecular \& Integrative Physiology, 163, 388-395.

Frick, H., Kropf, C., Nentwig, W., 2007. Laboratory temperature preferences of the wolf spider Pardosa riparia (Araneae: Lycosidae). Bulletin of the British Arachnological Society, $14,45-48$.

Fumarola, C., Zerbini, A., Guidotti, G.G., 2001. Glutamine deprivation-mediated cell shrinkage induces ligand-independent CD95 receptor signaling and apoptosis. Cell Death and Differenciation, 8, 1004-1013.

Gaillou, E., Delaunay, A., Rondeau, B., Bouhnik-le-Coz, M., Fritsch, E., Cornen, G., Monnier, C., 2008. The geochemistry of gem opals as evidence of their origin. Ore Geology Reviews, 34, 113-126.

Gusev, O., Nakahara, Y., Vanyagina, V., Malutina, L., Cornette, R., Sakashita, T., Hamada, N., Kikawada, T., Kobayashi, Y., Okuda, T. 2010. Anhydrobiosis-associated nuclear DNA 
damage and repair in the sleeping chironomid: linkage with radioresistance. PLoS ONE 5(11): e14008. doi:10.1371/journal.pone.0014008.

Hadley, N.F., 1994. Water relations of terrestrial arthropods. Academic Press, San Diego.

Hazel, M.H., lanowski, J.P., Christensen, R.J., Maddrell, S.H.P. O'Donnell M.J. 2003. Amino acids modulate ion transport and fluid secretion by insect Malpighian tubules. Journal of Experimental Biology, 206, 79-91.

Hendrickx, F., De Cock, K., De Bakker, D., Maelfait, J.-P., 2001. Differences in distribution and habitat of some cryptic species in the Pardosa lugubris group (Lycosidae, Araneae) in Belgium. Belgian Journal of Zoology, 131, 79-84.

Heydemann, B., 1970. Ökologische Untersuchungen zum Problem der halophilen und haloresistenten Spinnen. Bulletin du Muséum National d'Histoire Naturelle, 41, 226232.

Hidalgo, K., Laparie, M., Bical, R., Larvor, V., Bouchereau, A., Siaussat, D., Renault, D., 2013. Metabolic fingerprinting to salinity in the invasive ground Merizodus soledadinus at the Kerguelen Islands: does physiological plasticity and ecological range match? Journal of Insect Physiology, 59, 91-100.

Holdrich, D.M., Mayes, K.R., 1976. Blood volume and total water content of the woodlouse, Oniscus asellus, in conditions of hydration and desiccation. Journal of Insect Physiology, 22, 547-53.

Holmstrup, M., Bayley, M. 2013. Protaphorura tricampata, a euedaphic and highly permeable springtail that can sustain activity by osmoregulation during extreme drought. Journal of Insect Physiology, 59, 1104-1110.

Kasschau, M.R., Skisak C.M., Cook, J.P., Mills W.R. 1984. Beta-Alanine metabolism and high salinity stress in the sea anemone, Bunodosoma cavernata. Journal of Comparative Physiology B, 154, 181-186.

Koštál, V., Renault, D., Mehrabianová, A., Bastl, J. 2007. Insect cold tolerance and repair of chill-injury at fluctuating thermal regimes: Role of ion homeostasis. Comparative Biochemistry and Physiology Part A, 147, 231-238.

Levin, L.A., Talley, T.S., 2000. Influence of vegetation and abiotic environmental factors on salt marsh invertebrates, in: Weinstein, M.P., Kreeger D.A. (Eds.), Concepts and controversies in tidal marsh ecology. Kluwer Academic Publishing, Dordrecht, pp. 661-707. 
Misra, N., Gupta, A.K., 2005. Effect of salt stress on proline metabolism in two high yielding genotypes of green gram. Plant Science, 169, 331-339.

Moloney, C.L., Nicolson, S.W. 1984. Water relations and haemolymph composition of two intertidal spiders (Order Araneae). Journal of Experimental Marine Biology and Ecology, 83, 275-284.

Moya-Laraño, J., Macías-Ordóñez, R., Blanckenhorn, W.U., Fernández-Montraveta, C. 2008. Analysing body condition: mass, volume or density? Journal of Animal Ecology, 77, 1099-1108.

Moore, P.G., Francis C.H. 1985. On the water relations and osmoregulation of the beachhopper Orchestia gammarellus (Pallas) (Crustacea: Amphipoda). Journal of Experimental Marine Biology and Ecology, 94, 131-150.

Murphy, N.P., Framenau, V.W., Donnellan, S.C., Harvey, M.S., Park, Y.-C., Austin, A.D. 2006. Phylogenetic reconstruction of the wolf spiders (Araneae: Lycosidae) using sequences from the 12S rRNA, 28S rRNA, and NADH1 genes: Implications for classification, biogeography, and the evolution of web building behavior. Molecular Phylogenetics and Evolution, 38, 583-602.

Nentwig, W. 1987. Ecophysiology of spiders. Springer Verlag, Berlin.

Patrick, M.L., Bradley, T.J., 2000. The physiology of salinity tolerance in larvae of two species of Culex mosquitoes: the role of compatible solutes. Journal of Experimental Biology, 203, 821-830.

Pétillon, J., Ysnel, F., Canard, A., Lefeuvre, J.-C. 2005. Impact of an invasive plant (Elymus athericus) on the conservation value of tidal salt marshes in western France and implications for management: responses of spider populations. Biological Conservation, 126, 103-117.

Pétillon, J., Montaigne, W., Renault, D. 2009. Hypoxic coma as a strategy to survive inundation in a salt-marsh inhabiting spider. Biology Letters, 5, 442-445.

Pétillon, J., Lambeets, K., Montaigne, W., Maelfait, J.-P., Bonte, D. 2010a. Habitat structure modified by an invasive grass enhances inundation withstanding in a salt-marsh wolf spider. Biological Invasions, 12, 3212-3226.

Pétillon, J., Lambeets, K., Canard, A., Vernon, P., Ysnel F. 2010b. How do alterations in habitat structure by an invasive grass affect salt-marsh resident spiders? Annales Zoologici Fennici, 47, 79-89. 
Pétillon, J., Lambeets, K., Ract-Madoux, B., Vernon, P., Renault, D. 2011. Saline stress tolerance partly matches with habitat preference in ground-living wolf spiders. Physiological Entomology, 36: 165-172.

Pollard, A., Wyn Jones, R.G. 1979. Enzyme activities in concentrated solutions of glycinebetaine and other solutes. Planta, 144, 291-298.

Ramsay, J.A. 1950. Osmotic regulation in mosquito larvae Journal of Experimental Biology, 27, 145-157.

Renault, D., Lombard, M., Vingère, J., Laparie, M. 2014. Comparative physiological plasticity to saline conditions in native flies from the subantarctic Kerguelen Islands. Polar Biology. 10.1007/s00300-014-1605-8.

R Development Core Team, 2008. R: A language and environment for statistical computing. $R$ Foundation for Statistical Computing, Vienna.

Siaussat, D., Laparie, M., Maria, A., Renault, D. 2013. Heat shock protein responses to salinity, food deprivation, and temperature in the invasive ground beetle Merizodus soledadinus at the Kerguelen Islands. Polar Biology, 36, 201-209.

Sowers, A.D., Young, S.P., Grosell, M., Browdy, C.L., Tomasso, J.R. 2006. Hemolymph osmolality and and cation concentration in Litopenaeus vannamei during exposure to artificial sea salt or a mixed-ion solution: relationship to potassium flux. Comparative Biochemistry and Physiology - Part A: Molecular \& Integrative Physiology, 145, 176180.

Spencer, J.I., Gaston, K.J. 1999. Physiological diversity and its ecological implications. Blackwell, Oxford.

Stewart, G.R., Lee, J.A. 1974. The role of proline accumulation in Halophytes. Planta, 120, 279-289.

Tufova, A., Tuf, I. 2005. Survival under water - comparative study of millipedes (Diplopoda), centipedes (Chilopoda) and terrestrial isopods (Oniscidea). Contributions to Soil Zoology in Central Europe I. Tajovský, K., Schlaghamerský, J. \& Pižl, V. (eds.): 195-198. ISB AS CR, České Budějovice, 2005. ISBN 80-86525-04-X.

Walter, A., Cadenhead, N., Sze Weii Lee, V., Dove, C., Milley, E., Elgar, M.A. 2012. Water as an essential resource: orb web spiders cannot balance their water budget by prey alone. Ethology, 118, 534-542. 
Witteveen, J., Verhoef, H.A., Letschert, J.P.W. 1987. Osmotic and ionic regulation in marine littoral Collembola. Journal of Insect Physiology, 33, 59-66.

Witteveen, J., Joose, E.N.G. 1988. The effects of inundation on marine littoral Collembola. Holarctic Ecology, 11, 1-7.

Wyatt, T.D. 1986. How a subsocial intertidal beetle, Bledius spectabilis, prevents flooding and anoxia in its burrow. Behavioral Ecology and Sociobiology, 19, 323.

Xia, J., Mandal, R., Sinelnikov, I., Broadhurst, D., Wishart, D.S. 2012. MetaboAnalyst 2.0 - a comprehensive server for metabolomics data analysis. Nucleid Acids Research, doi: 10.1093/nar/gks374.

Yancey, P.H. 2005. Organic osmolytes as compatible, metabolic and counteracting cytoprotectants in high osmolarity and other stresses. Journal of Experimental Biology, 208, 2819-2830.

Zeiske, W. 1992. Insect ion homeostasis. Journal of Experimental Biology, 172, 323-334. 


\section{Figure captions}

Figure 1. Mean survival duration ( $\mathrm{Lt}_{50}$ : mean $\pm \mathrm{SE}$, days) of Pardosa saltans, $P$. purbeckensis and Arctosa fulvolineata females along the three salinity levels (probit analysis: different successive letters indicate significant differences at $\alpha=0.05$ ).

Figure 2. Box plot of the body water content ([final fresh mass - final dry mass] / final dry mass) according to salinity level in female (a) Pardosa saltans, (b) Pardosa purbeckensis and (c) Arctosa fulvolineata. Boxes represent upper and lower quartiles; the body water content median is represented by the black line within each box. Whiskers indicate $90 \%$ percentile values, open circles represent outlier values.

Figure 3. Hemolymph concentration of $\mathrm{Na}^{+}, \mathrm{Mg}^{2+}, \mathrm{K}^{+}$and $\mathrm{Ca}^{2+}$ ions (pmol ion /mg of dry hemolymph mass) in spiders exposed at salinities of 0,35 or $70 \%$ for one (Pardosa saltans) or two (Pardosa purbeckensis and Arctosa fulvolineata) weeks. Due to the small number of replicates for each experimental condition, errors are given as absolute uncertainty for each ion concentration.

Figure 4. Multivariate analysis (PLS-DA) on metabolomics data. (A) Sample projection (5 samples per experimental group) onto the first PLS-DA discriminant plane of female Pardosa saltans exposed at salinities of 0 (red dots), 35 (green dots) or 70 (bleu dots) \%o for two weeks. Each dot represents an individual sample (one female). Ellipses represent the $95 \%$ confidence region for each experimental group, i.e. the region that contains $95 \%$ of all samples. Permutation tests $(N=1000)$ validated the model $(P<0.01)$. (B) Variable importance plot showing the metabolites that contributed the most to the first axis (based on their VIP scores). Variables with VIP scores $>1.3$ were retained in the full model (all metabolites), which resulted in VIP scores $>0.8$ in the reduced model (non-varying metabolites were removed). The colored squares, ranging from green to red, on the right represent the relative metabolite amount in the samples; green-colored squares indicate low metabolite amount, a red color indicates a high metabolite amount, and a yellowcolored square reflects an intermediate amount. 
Figure 5. Multivariate analysis (PLS-DA) on metabolomics data. (A) Sample projection (5 samples per experimental group) onto the first PLS-DA discriminant plane of female Pardosa purbeckensis exposed at salinities of 0 (red dots), 35 (green dots) or 70 (bleu dots) \%o for two weeks. Each dot represents an individual sample (one female). Ellipses represent the $95 \%$ confidence region for each experimental group, i.e. the region that contains $95 \%$ of all samples. Permutation tests $(N=1000)$ validated the model $(P<0.01)$. (B) Variable importance plot showing the metabolites that contributed the most to the first axis (based on their VIP scores). Variables with VIP scores $>1.3$ were retained in the full model, which resulted in VIP scores $>0.8$ in the reduced model. The colored squares, ranging from green to red, on the right represent the relative metabolite amount in the samples; green-colored squares indicate low metabolite amount, a red color indicates a high metabolite amount, and a yellow-colored square reflects an intermediate amount.

Figure 6. Multivariate analysis (PLS-DA) on metabolomics data. (A) Sample projection (5 samples per experimental group) onto the first PLS-DA discriminant plane of female Arctosa fulvolineata exposed at salinities of 0 (red dots), 35 (green dots) or 70 (bleu dots) \%o for two weeks. Each dot represents an individual sample (one female). Ellipses represent the 95\% confidence region for each experimental group, i.e. the region that contains $95 \%$ of all samples. Permutation tests $(N=1000)$ validated the model $(P<0.01)$. (B) Variable importance plot showing the metabolites that contributed the most to the first axis (based on their VIP scores). Variables with VIP scores $>1.3$ were retained in the full model, which resulted in VIP scores $>0.8$ in the reduced model. The colored squares, ranging from green to red, on the right represent the relative metabolite amount in the samples; green-colored squares indicate low metabolite amount, a red color indicates a high metabolite amount, and a yellow-colored square reflects an intermediate amount. 
Table 1. Mean $( \pm 3 \%$ confidence limit) hemolymph concentrations (pmole ion /mg of dry hemolymph mass) of sodium; magnesium and potassium, $\left[\mathrm{Na}^{+}\right],\left[\mathrm{Mg}^{2+}\right]$ and $\left[\mathrm{K}^{+}\right]$, respectively, in Pardosa saltans, Pardosa purbeckensis and Arctosa fulvolineata) after one day acclimation at null salinity at $20^{\circ} \mathrm{C}$.

\begin{tabular}{lccc}
\hline Species & $\begin{array}{c}{\left[\mathrm{Na}^{+}\right]} \\
\mathrm{pmole} / \mathrm{mg}\end{array}$ & $\begin{array}{c}{\left[\mathrm{Mg}^{2+}\right]} \\
\mathrm{pmole} / \mathrm{mg}\end{array}$ & $\begin{array}{c}{\left[\mathrm{K}^{+}\right]} \\
\mathrm{pmole} / \mathrm{mg}\end{array}$ \\
\hline P. saltans & $984 \pm 29$ & $113 \pm 3$ & $64 \pm 2$ \\
P. purbeckensis & $2203 \pm 66$ & $26 \pm 1$ & $123 \pm 4$ \\
A. fulvolineata & $1918 \pm 57$ & $18 \pm 1$ & $104 \pm 3$ \\
\hline
\end{tabular}




\section{ACCEPTED MANUSCRIPT}

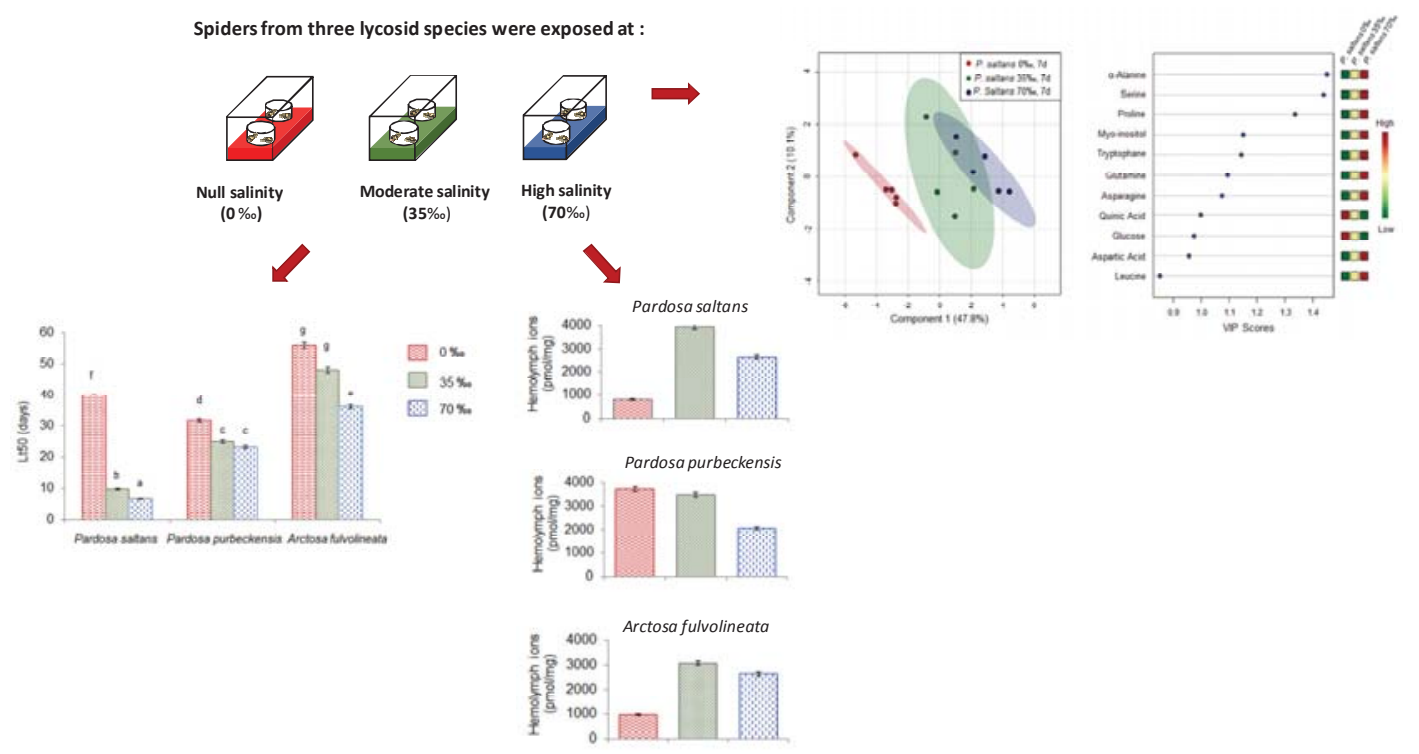


- The effect of salinity on the survival and physiology of three lycosids was compared

- Spiders were individually exposed at three salinity conditions (0\%, 35\%o and $70 \%$ o)

- Survival, body water content, hemolymph ions and metabolites were measured

- Survival of the forest species was quickly hampered at moderate and high salinities

- Accumulation of hemolymph $\mathrm{Na}^{+}$and amino acids enhanced survival of salt marsh spiders 


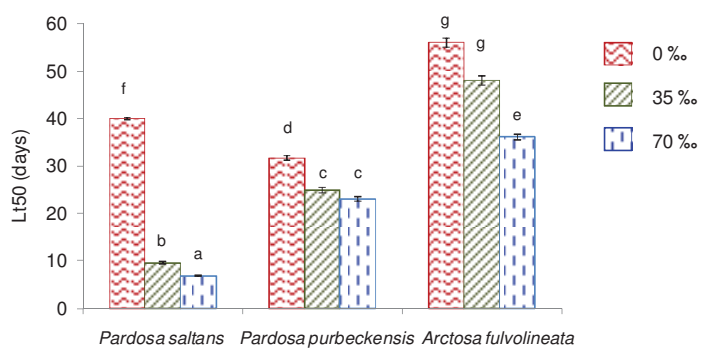

Fig. 1 


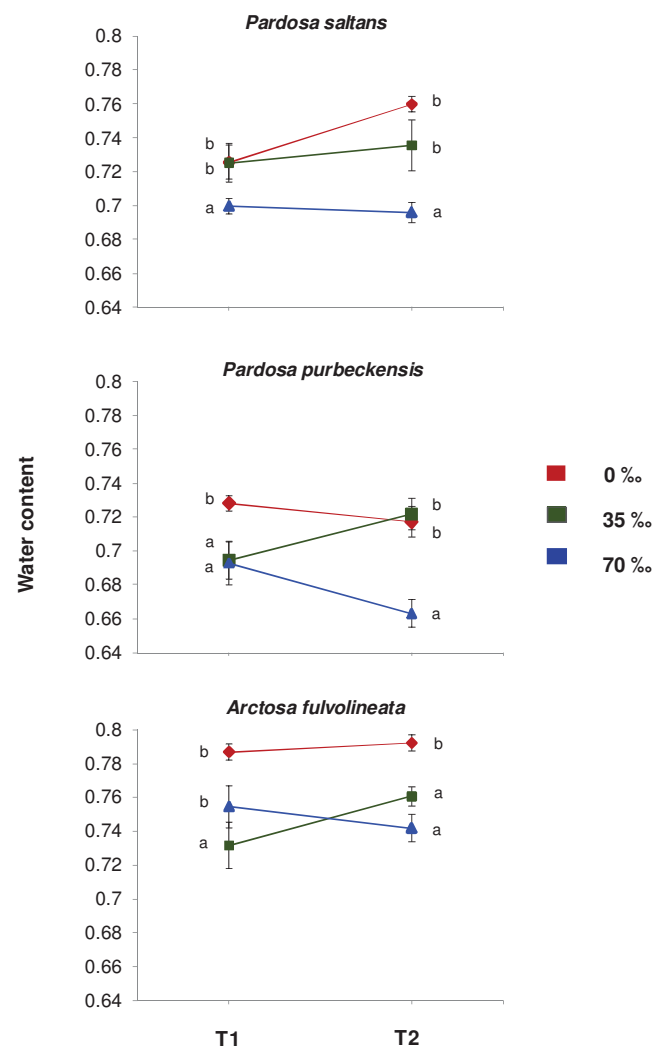

Fig. 2

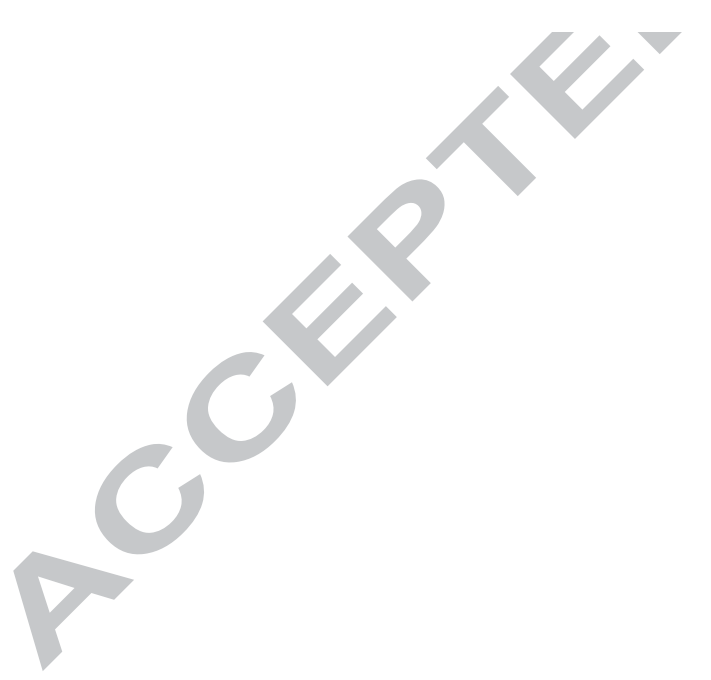




\section{ACCEPTED MANUSCRIPT}
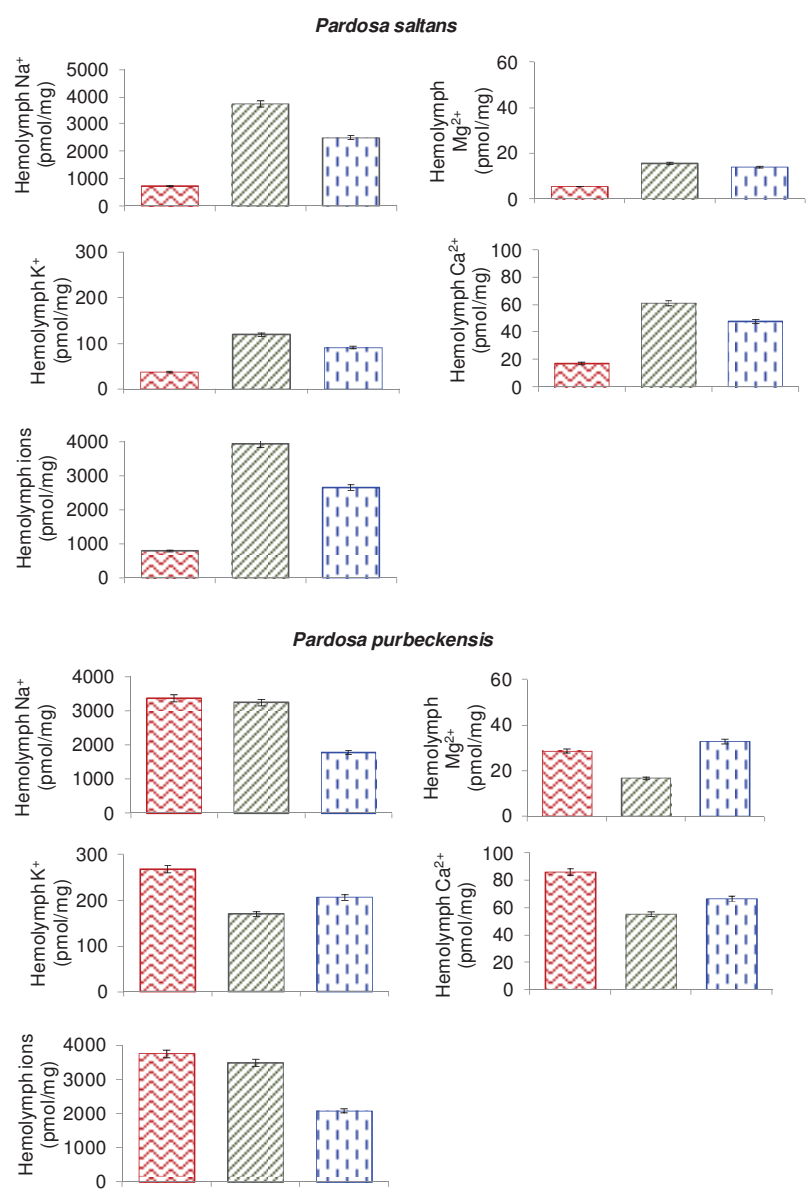


\section{ACCEPTED MANUSCRIPT}
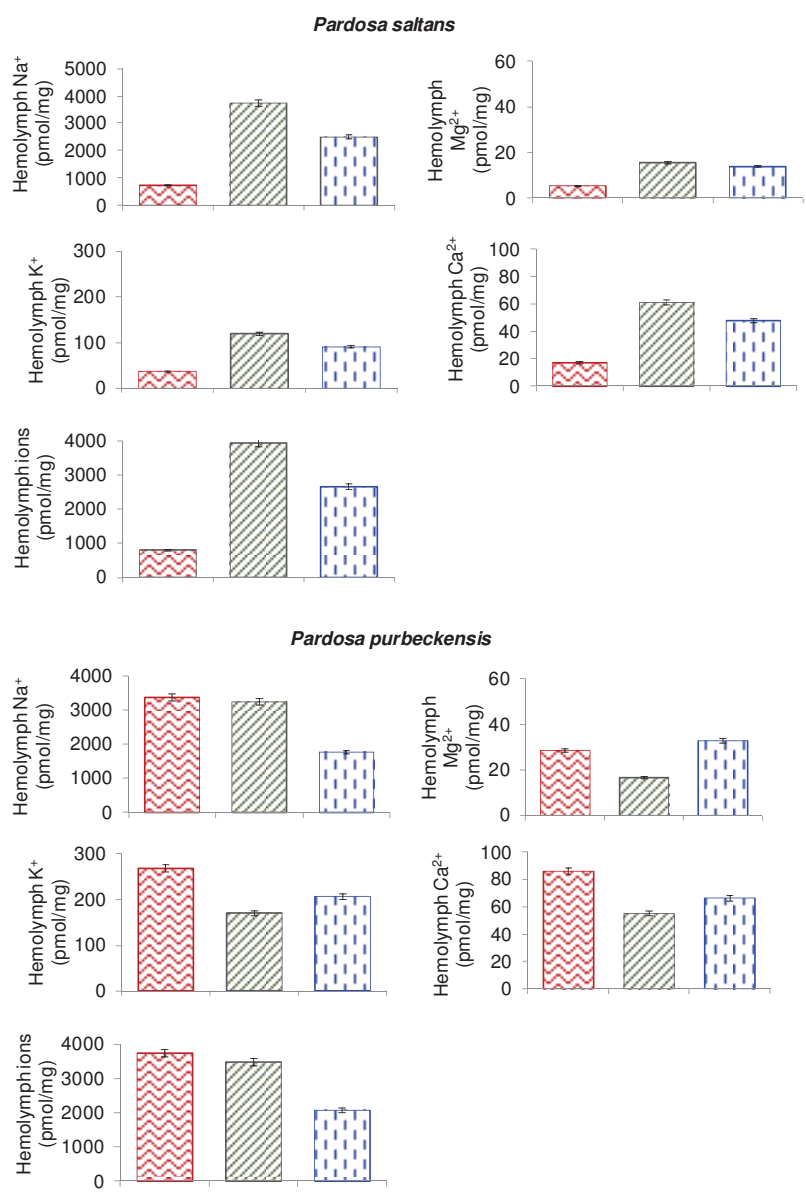

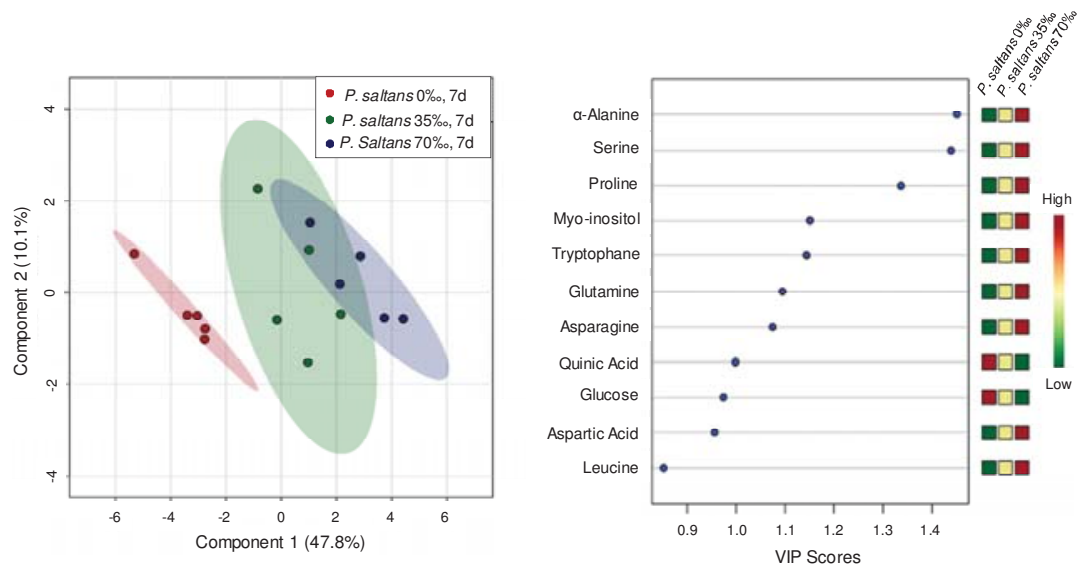

Fig. 4 

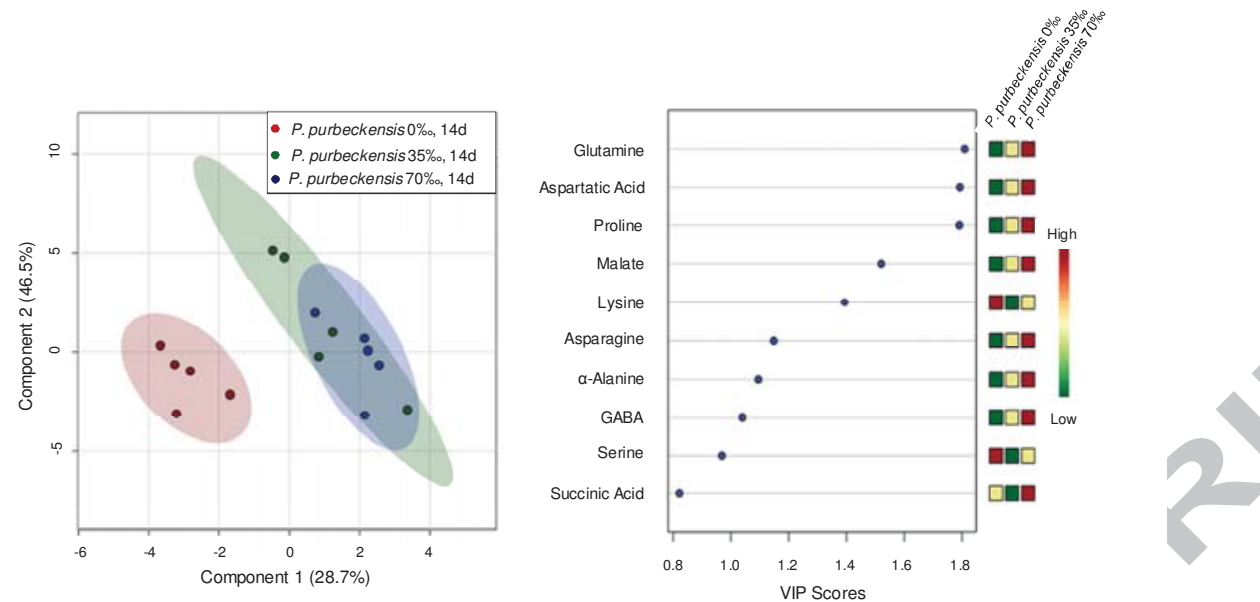

Fig. 5 

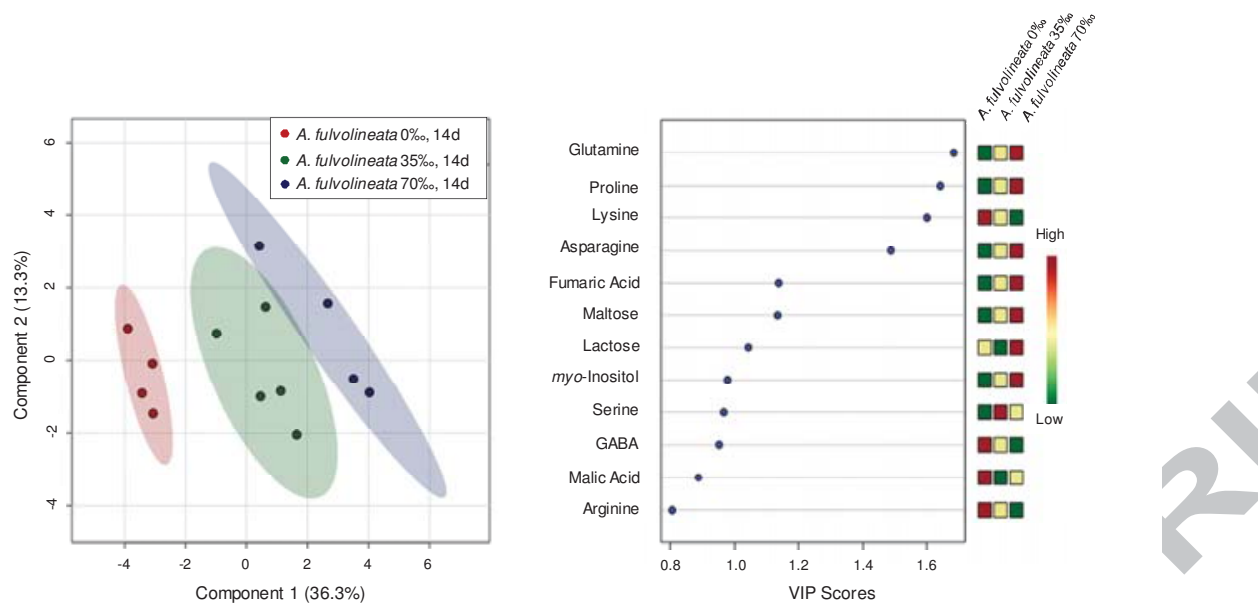

Fig. 6 